\title{
Model Pembelajaran Search, Solve, Create And Share (SSCS): Dampak Terhadap Kemampuan Penalaran Matematis Dan Motivasi Belajar Peserta Didik
}

\author{
Riski Meilindawati ${ }^{1)}$, Netriwati ${ }^{2)}$, Siska Andriani ${ }^{3)}$ \\ 1),2),3) Pendidikan Matematika UIN Raden Intan Lampung \\ e-mail: meilindariski00@gmail.com
}

\begin{abstract}
Penelitian ini betujuan untuk mengetahui pengaruh model pembelajaran Search, Solve, Create and Share (SSCS) terhadap kemampuan penalaran matematis dan motivasi belajar peserta didik. Penelitian ini menggunakan jenis penelitian Quasy Experimental Desaign. Populasi dalam penelitian ini adalah seluruh siswa kelas VIII SMP Negeri 2 Belitang Mulya. Sampel diambil dua kelas yaitu kelas VIII A sebagai kelas eksperimen yang memperoleh pembelajaran menggunakan model Search, Solve, Create and Share (SSCS) dan kelas VIII B sebagai kelas kontrol yang memperoleh pembelajaran konvensional dengan menggunakan teknik simple random sampling. Analisis data pada penelitian ini menggunakan Uji Multivariate Analysis of Variance (Manova). Hasil analisis data menunjukkan menunjukkan bahwa: (1) terdapat pengaruh model pembelajaan Search, Solve, Create, and Share (SSCS) terhadap kemampuan penalaran matematis peserta didik, (2) terdapat pengaruh model pembelajaan Search, Solve, Create, and Share (SSCS) terhadap motivasi belajar peserta didik, (3) terdapat pengaruh model pembelajaan Search, Solve, Create, and Share (SSCS) terhadap kemampuan penalaran matematis dan motivasi belajar peserta didik.
\end{abstract}

Keywords: model pembelajran Search, Solve, Create and Share (SSCS), kemampuan penalaran matematis, motivasi belajar

\section{PENDAHULUAN}

Kemampuan penalaran matematis adalah hal yang perlu dan penting dimiliki peserta didik, karena kemampuan penalaran matematis merupakan salah satu hal yang menentukan keberhasilan proses pembelajaran matematika. Barrody (Santosa, Negara, dan Bahri 2020) mengemukakan pentingnya memiliki kemampuan penalaran matematis adalah penalaran matematis sangat membantu individu tidak hanya mengingat fakta, aturan, langkah-langkah penyelesaian masalah, tetapi juga menggunakan keterampilan bernalarnya dalam melakukan pendugaan atas dasar pengalamannya sehingga yang bersangkutan akan mendapatkan pemahaman konsep matematika yang saling berkaitan dan belajar secara bermakna atau meaningfull learning.

Menurut Gardner (Konita, Asikin, dan Asih 2019) mengatakan bahwa penalaran matematis adalah kemampuan untuk menganalisis, menggeneralisasi, mensintesis / mengintegrasikan, membenarkan dengan baik dan menyelesaikan masalah non-rutin. Sementara Ball dan Bass (Mirlanda, Nindiasari, dan Syamsuri 2020) mengemukakan bahwa penalaran adalah "keterampilan dasar" matematika dan diperlukan untuk sejumlah tujuan untu memahami konsep matematika, untuk menggunaka ide dan prosedur matematis secara fleksibel dan untuk merekonstruksi yang dipahami, tetapi pengetahuan matematika yang terlupakan. Menurut Depdiknas (Gorat dan Haryadi 
2020) mengungkapkan bahwa, materi matematika dan penalaran matematis adalah dua hal yang saling berkaitan, yaitu materi matematika dipahami melalui penalaran dan penalaran dipahami dan dilatih melalui belajar matematika. Menurut (Izzah dan Azizah 2019) penalaran matematika memegang peranan yang sangat penting dalam proses berpikir peserta didik karena jika keterampilan penalaran peserta didik tidak dikembangkan, pembelajaran matematika hanya akan menjadi materi yang mengikuti serangkaian prosedur dan meniru contoh tanpa mengetahui maknanya.

Kemampuan penalaran matematis akan berkembang dengan baik apabila peserta didik dapat menerima pelajaran matematika. Agar peserta didik dapat menerima pelajaran matematika perlu ditanamkan motivasi belajar peserta didik terhadap pelajaran matematika. Namun saat ini masalah yang masih banyak ditemui dari peserta didik adalah menganggap matematika adalah pelajaran yang sulit, sehingga rendahnya motivasi belajar peserta didik dalam mengikuti pembelajaran matematika. Menurut Umairah dan Zulfah (2020) motivasi belajar matematika adala dorongan baik dari internal maupun eksternal yang mengubah energi pada diri individu untuk menggerakkan perilaku serta mempertahankannya, sehingga terjadi perubahan tingkah laku yang mengarah pada aktivitas belajar matematika. Menurut Mc. Donald (Sardiman, 2016) mengatakan bahwa motivasi adalah perubahan energi dalam diri seseorang yang ditandai dengan mulai munculnya "feeling" dan didahului dengan tanggapan terhadap adanya tujuan. Menurut Sudjana (Ningtiyas dan Surjanti 2021) motivasi belajar tercermin dari sikap perhatian yang diberikan peserta didik selama proses pembelajaran, serta memiliki semangat dan tanggung jawab dalam melaksanakan tugas yang diberikan oleh guru.

Hakikat motivasi belajar adalah dorongan internal dan eksternal pada peserta didik yang sedang dalam proses belajar untuk menghadirkan perubahan tingkah laku, pada umumnya dengan beberapa indikator atau unsur yang mendukung. Indikator motivasi belajar dapat diklasifikasikan sebagai berikut (1) adanya hasrat dan keinginan berhasil; (2) adanya dorongan dan kebutuhan dalam belajar; (3) adanya harapan dan cita-cita masa depan (4) adanya penghargaan dalam belajar; (5) adanya kegiatan yang menarik dalam pembelajaran; (6) adanya lingkungan yang kondusif sehingga memungkinkan peserta didik dapat belajar dengan baik (Uno 2013). Motivasi belajar sangat penting dalam kegiatan pembelajaran guna untuk menumbuhkan hasrat dan keinginan untuk belajar serta motivasi akah menentukan intensitas usaha belajar yang dilakukan oleh peserta didik. Menurut Gianistika (Destyana dan Surjanti 2021) keberadaan motivasi belajat adalah suatu hal yang diperlukan dalam kegiatan pembelajaran karena dapat menciptakan perasaan semangat dan senang dalam belajar. Dengan adanya motivasi yang baik dalam belajar maka kemampuan penalaran matematis akan berkembang dengan optimal.

Namun kenyataan di lapangan menunjukkan bahwa kemampuan penalaran matematis dan motivasi belajar peserta didik siswa belum sesuai dengan yang diharapkan. Seperti halnya masih banyak ditemukan peserta didik di SMP Negeri 2 Belitang Mulya yang memiliki kemampuan penalaran matematis dan motivasi belajar yang rendah. Hal tersebut dibuktikan dengan hasil wawancara dengan salah satu guru bidang studi di SMP Negeri 2 Belitang Mulya, dijelaskan bahwa proses pembelajaran matematika di kelas VIII peserta didik masih kurang aktif dan kemampuan penalaran matematis peserta didik masih sangat kurang. Pada pembelajaran matematika peserta didik di SMPN 2 Belitang Mulya juga masih sulit dibina selama proses pembelajaran, sikap peserta didik yang malas-malasan dalam proses pembelajaran, dikarenakan motivasi belajar peserta didik masih rendah. 
Selain dibuktikan dengan hasil wawancara, rendahnya kemampuan penalaran matematis peserta didik juga dibuktikan dari hasil pra penelitian yang telah dilakukan di SMPN 2 Belitang Mulya dapat dilihat pada Tabel 1, berikut:

Tabel 1. : Nila Pra-Penelitian Kemampuan Penalaran Matematis Peserta Didik

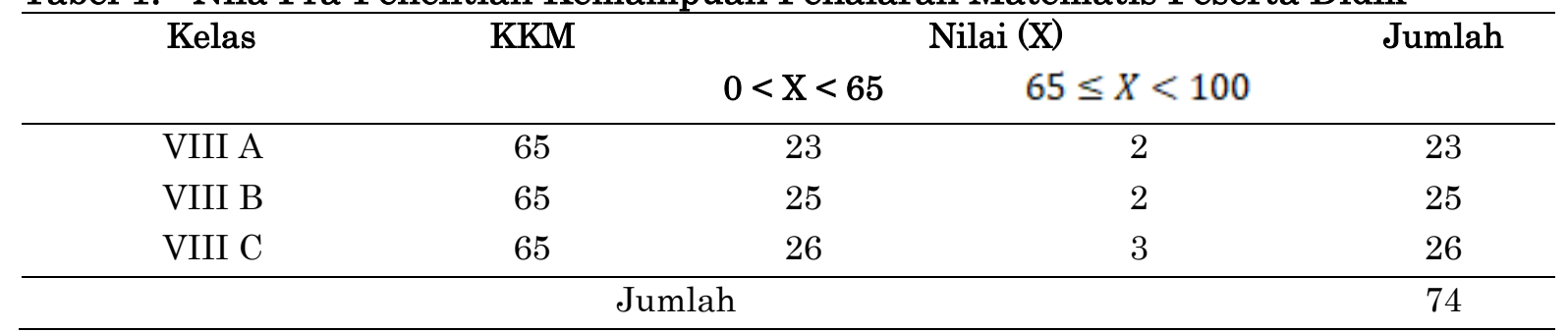

Berdasarkan Tabel 1 didapat hasil bahwa dari 74 peserta didik masih banyak peserta didik yang memperoleh nilai dibawah Kriteria Ketuntasan Minimal (KKM), dan hanya ada beberapa peserta didik yang lulus atau memperoleh hasil di atas KKM. Hal tersebut dapat disebabkan karena tidak adanya keseriusan peserta didik dalam proses mengerjakan soal pra yang telah diberikan sehingga hanya mengandalkan jawaban teman, dan materi yang diberikan sudah lama dipelajari sehingga memungkinkan peserta didik lupa dengan materi tersebut.

Faktor penyebab rendahnya motivasi belajar dan kemampuan penalaran matematis ini antara lain siswa yang masih menganggap pelajaran matematika adalah suatu pelajaran yang sulit, enggan dan malas mempelajari matematika menyebabkan kurangnya motivasi belajar peserta didik. Faktor lainnya yaitu ketidaktepatan model pembelajaran yang digunakan guru selama proses pembelajaran. Masih banyak ditemukan guru yang menggunakan model pembelajaran yang dalam pelaksanaannya menempatkan guru sebagai pihak yang paling berperan aktif sedangkan peserta didik hanya sebagai pihak yang menerima materi pembelajaran. Dalam pelaksanaan, seharusnya peserta didik yang dituntut aktif dalam pembelajaran sesuai dengan yang dijelaskan pada kurikulum yang sekarang.

Untuk mengatasi hal ini, seharusnya guru menggunakan model pembelajaran yang tepat dalam menumbuhkan kemampuan penalaran matematis dan motivasi belajar dalam diri peserta didik. Salah satu model pembelajaran yang dipandandang tepat untuk meningkatkan motivasi belajar dan kemampuan penalaran matematis peserta didik adalah Search, Solve, Create and Share (SSCS). Model pembelajaran Search, Solve, Create and Share (SSCS) adalah model yang mengarahkan peserta didik untuk dapat menguraikan, menghubungkan dan menganalisis masalah hingga sampai tahap penyelesaian masalah sehingga menuntut peserta didik untuk aktif berdiskusi dalam kelompok-kelompok kecil selama proses pembelajaran (Widyati dan Irawati 2020). Search, Solve, Create, and Share (SSCS) adalah salah satu model pembelajaran yang menekankan pada penerapan pendekatan ilmiah atau berpikir sistematis, logis, teratur dan tepat (Astuti, Suweken, dan Waluyo 2018).

Menurut Saputra dkk (Putriyana, Auliandari, dan Kholillah 2020) kelebihan model pembelajaran SSCS yaitu: 1) dalam model SSCS, peserta didik pada awal pembelajaran sudah dihadapkan pada masalah-masalah nyata, sehingga peserta didik tertarik untuk belajar, 2) dalam model SSCS, peserta didik lebih sering belajar secara berkelompok dan guru lebih banyak memberikan kesempatan kepada peserta didik untuk dapat menyelesaikan masalahnya sendiri, dan 3) kegiatan peserta didik dalam pembelajaran menggunakan model SSCS sangat bervariasi mulai dari diskusi, melakukan percobaan, dan presentasi yang membuat peserta didik semangat dan tidak merasa bosan selama mengikuti pembelajaran. sedangkan kekurangan model 
SSCS ini menurut peserta didik masih belum terbiasa menggunakan model SSCS, sehingga peserta didik hanya mendegarkan dan mencatat keterangan yang diberikan guru atau dari temannya.

Menurut Ubaidah dan Wijayanti (2020) model pembelajaran SSCS ini memiliki ciri yaitu proses pembelajarannya terdiri dari empat fase, yaitu pertama fase search yang bertujuan untuk mengidentifikasi masalah, kedua fase solve yang bertujuan untuk merencanakan penyelesaian masalah, ketiga fase create yang bertujuan untuk melaksanakan penyelesaian masalah, dan keempat adalah fase share yang bertujuan untuk menyampaikan penyelesaian masalah yang dilakukan. Dalam pelaksanaannya penelitian juga dibantu dengan metode reward and punishment agar dalam proses pembelajaran memberikan kesan yang menyenangkan tetapi tetap mudah dimengerti. Menurut Shoimin (2018) reward sebagai alat pendidikan diberikan jika seorang peserta didik melakukan sesuatu yang baik, telah berhasil mencapai sebuah tahap perkembangan tertentu, atau tercapainya tujuan yang diinginkan oleh anak tersebut. Ngalim Purwanto (2014) berpendapat bahwa hukuman atau punishment adalah penderitaan yang diberikan oleh seseorang (orang tua, guru, dan lain-lain) setelah seseorang melakukan suatu pelanggaran, kejahatan, atau kesalahan.

Model pembelajaran Search, Solve, Create, and Share (SSCS) dapat memicu peserta didik lebih aktif dalam proses pembelajaran karena dapat memberikan kesempatan kepada peserta didik untuk mengasah kemampuannya. Dalam pelaksanaan juga dibantu dengan metode reward and punishment sehingga memberikan kesan yang menyenangkan tetapi tetap mudah dimengerti. Penelitian terdahulu yang dilakukan oleh Copriady dan Rery (2016), mengungkapkan bahwa terdapat perbedaan yang signifikan motivasi dan hasil belajar pada peserta didik yang menggunakan pembelajaran Pembelajaran PBS Tipe Search, Solve, Create Dan Share (SSCS) dengan Molymod dengan yang tidak menggunakan model Pembelajaran PBS Tipe Search, Solve, Create Dan Share (SSCS) dengan Molymod. Model pembelajaran Search, Solve, Create, and Share (SSCS) telah diteliti oleh Ahmad Safi'I. Penelitiannya menunjukkan bahwa model pembelajaran Search, Solve, Create, and Share (SSCS) berdampak pada kemampuan berpikir reflektif dan kemampuan pemecahan masalah matematis peserta didik (Safi'i 2020).

Berdasarkan uraian di atas, ada beberapa tujuan penelitian ini yaitu untuk mengetahui: (1) ada atau tidak pengaruh model pembelajaan Search, Solve, Create, and Share (SSCS) terhadap motivasi belajar peserta didik, (2) ada atau tidak pengaruh model pembelajaan Search, Solve, Create, and Share (SSCS) terhadap kemampuan penalaran matematis peserta didik, (3) ada atau tidak pengaruh model pembelajaan Search, Solve, Create, and Share (SSCS) terhadap motivasi belajar dan kemampuan penalaran matematis peserta didik.

\section{METODE}

Metode penelitian yang digunakan pada penelitian ini adalah Quasy Experimental Desaign dengan desain penelitian yang digunakan dalam penelitian ini berbentuk post-test only control grup desaign.

Teknik pengambilan sampel dalam penelitian ini adalah teknik simple random sampling. Populasi pada penelitian ini adalah seluruh siswa kelas VIII SMP Negei 2 Belitang Mulya, tahun ajaran 2020/2021. Sampel penelitian ini adalah kelas VIII A dan kelas VIII B. Teknik pengumpulan data yaitu angket motivasi belajar dan tes kemampuan penalaran matematis. Pengujian hipotesisi penelitian, menggunakan Uji 
Multivariate Analisys of Variance (Manova) pada taraf signifikasi $\alpha=0,05$ dengan terlebih dahulu melakukan uji prasyarat yaitu uji normalitas dan homogenitas.

\section{HASIL DAN PEMBAHASAN}

Dari hasil penelitian yang disajikan untuk menganalisis dan mengungkapkan secara mendalam hasil penelitian yang digunakan untuk menjawab rumusan masalah dan menguji hipotesis penelitian. Data penelitian meliputi data motivasi belajar pada kelas model Search, Solve, Create and Share (SSCS) dan konvesional dan kemampuan penalaran matematis pada kelas Search, Solve, Create and Share (SSCS) dan konvesional.

Data dianalisis menggunakan deskriptif dan statistic inferensial. Data yang dideskripsikan berupa hasil angket motivasi belajar dan tes akhir kemampuan penalaran matematis peserta didik pada kelas eksperimen dan kelas kontrol. Sebelum menguji hipotesis, terlebih dahulu data masing-masing kelompok diuji normalitas dan homogenitas. Data yang digunakan untuk pengujian tersebut adalah skor motivasi belajar dan skor kemampuan penalaran matematis peserta didik. Hasil uji normalitas menggunakan uji Kolmogorov-smirnov dengan bantuan program SPSS-22 terangkum pada Tabel 2 berikut ini:

Tabel 2. Uji Normalitas

\begin{tabular}{ccccc} 
Variabel & \multirow{2}{*}{ Kategori } & \multicolumn{2}{c}{ Kolmogorov-smirnov } \\
& & Statistik & dF & Sig. \\
\hline \multirow{2}{*}{ Kemampuan penalaran matematis } & Eksperimen & 0,092 & 28 & 0,200 \\
& Kontrol & 0,097 & 30 & 0,200 \\
Motivasi Belajar & Rendah & 0,210 & 10 & 0,200 \\
& Sedang & 0,118 & 40 & 0,168 \\
& Tinggi & 0,209 & 8 & 0,200 \\
\hline
\end{tabular}

Hasil perhitungan pada Tabel 2 menunjukkan bahwa nilai signifikansi pada semua kelompok Sig $>0,05$. Dengan demikian dapat disimpulkan kedua kelompok data berasal dari populasi yang berdistribusi normal. Selanjutnya dilakukan uji Barlett dengan bantuan program SPSS-22 terangkum pada Tabel 3 berikut ini:

Tabel 3. Uji Homogenitas

\begin{tabular}{ccccc}
\hline Variabel & Levene Statistic & df1 & df2 & Sig. \\
\hline Kemampuan Penalaran Matematis & 0,283 & 1 & 56 & 0,597 \\
Motivasi Belajar & 0,149 & 1 & 56 & 0,701 \\
\hline
\end{tabular}

Hasil perhitungan pada Tabel 3 menunjukkan bahwa untuk kedua kelompok masing-masing data diperoleh nilai Sig. $>0,05$. Dengan demikian dapat disimpulkan kedua kelompok data memiliki varians yang homogen. Hal ini berarti motivasi belajar dan kemampuan penalaran matematis peserta didik dari kelompok yang diterapkan model pembelajaran Search, Solve, Create and Share (SSCS) dan model pembelajaran konvensional memiliki varians yang sama (homogen).

Uji prasyarat menunjukkan masing-masing data tersebut normal dan homogen Selanjutnya dilakukan uji hipotesis untuk mendapatkan data dan pengaruh dari model pembelajaran dengan menggunakan uji MANOVA. Untuk pengujian hipotesis pertama dan kedua dilakukan berdasarkan pada Test of Between-Subject Effect. Hasil analisis disajikan pada Tabel 4. 
Tabel 4. Test of Between-Subject Effect

\begin{tabular}{llcrrrr}
\hline Source & Dependent Variable & $\begin{array}{c}\text { Type III Sum of } \\
\text { Squares }\end{array}$ & \multicolumn{1}{c}{ Df } & \multicolumn{1}{c}{ Square } & \multicolumn{1}{c}{ F } & \multicolumn{1}{c}{ Sig. } \\
\hline Kelas & Penalaran Matematis & 475.784 & 1 & 475.784 & 11.658 & 0.001 \\
& Motivasi Belajar & 535.963 & 1 & 535.963 & 4.275 & 0.043 \\
\hline
\end{tabular}

Berdasarkan Tabel 5, untuk uji hipotesis pertama, hasil analisis diperoleh nilai Sig. $=0,001$; Sig<0,05. Jadi nilai signifikan, berarti $H_{0}$ "ditolak" dan $H_{1}$ "diterima". Dapat disimpulkan, bahwa terdapat pengaruh model pembelajaran Search, Solve, Create and Share (SSCS) terhadap kemampuan penalaran matematis peserta didik.

Untuk uji hipotesis kedua, nilai sig $=0,043$; sig $<0,05$. Jadi nilai signifikan, artinya $H_{0}$ "ditolak" dan $H_{1}$ "diterima". Kesimpulannya, bahwa terdapat pengaruh model pembelajaran Search, Solve, Create and Share (SSCS) terhadap motivasi belajar peserta didik.

Pada uji hipotesis pertama, pengujian pengaruh model pembelajaran terhadap kemampuan penalaran matematis dan motivasi belajar peserta didik secara bersamaan. Hasil analisis dapat disajikan pada Tabel 5.

Tabel. 5 Uji Multivariate

\begin{tabular}{ll|r|r|r|r|c}
\hline Effect & & Value & F & Hypothesis df & Error df & Sig. \\
\hline Kelas & Pillai's Trace & 0.188 & $6.355^{\mathrm{b}}$ & 2.000 & 55.000 & 0.003 \\
& Wilks' Lambda & 0.812 & $6.355^{\mathrm{b}}$ & 2.000 & 55.000 & 0.003 \\
& Hotelling's Trace & 0.231 & $6.355^{\mathrm{b}}$ & 2.000 & 55.000 & 0.003 \\
& Roy's Largest Root & 0.231 & $6.355^{\mathrm{b}}$ & 2.000 & 55.000 & 0.003 \\
\hline
\end{tabular}

Hasil analisis menunjukkan bahwa untuk Pillai's Trace, Wilk Lamda, Hotelling's Trace, Roy's Largest Root nilai sig. $<0,05$ atau signifikan. Ini berarti, $H_{0}$ ditolak dan $H_{1}$ diterima. Dapat disimpulkan bahwa terdapat perbedaan motivasi belajar dan kemampuan penalaran matematis peserta didik pada model Search, Solve, Create and Share (SSCS) dengan siswa pada model konvensional.

Berdasarkan hasil penelitian yang telah dilakukan melalui pemberian tes dan angket diakhir pembelajaran, hasil kemampuan penalaran matematis peserta didik yaitu dengan model pembelajaran Search, Solve, Create and Share (SSCS) lebih besar dari pada kemampuan penalaran matematis peserta didik yang menggunakan model pembelajaran konvensional. Dimana dalam proses pembelajaran dengan model SSCS membuat siswa lebih aktif dalam proses pembelajaran dan menuntutpeserta didik untuk menggunakan kemampuan bernalarnya dalam menyelesaikan permasalahan.

Proses pembelajaran dengan menggunakan model search, solve, create and share (SSCS) dengan bantuan reward and punishment ini peserta dituntut untuk berperan aktif selama proses pembelajaran, pembelajaran dimulai dengan mengajukan pertanyaan tentang materi sebelumnya yang berkaitan dengan materi yang akan diajarkan dengan memberikan reward kepada peserta didik yang bisa menjawab. Kemudian menjelaskan terlebih dahulu tujuan pembelajaran, menerangkan langkahlangkah pembelajaran. Selanjutnya peneliti menjelaskan materi statistika secara umum. Kemudian peneliti membagi peserta didik ke dalam beberapa kelompok. Kemudian peneliti membagikan LKPD tentang materi statistika. Peserta didik memulai diskusi sesuai langkah-langkah LKPD yang telah diberikan. Pada saat berlangsungnya proses pembelajaran peneliti memberikan kesempatan kepada peserta didik untuk bertanya jika belum paham dengan materi. Setelah peserta didik menyelesaikan permasalahan yang terdapat dalam LKPD, peneliti meminta salah 
satu perwakilan kelompok untuk mengerjakan satu soal di papan tulis, dan memberikan reward jika mampu menjawab soal dengan benar. Melalui pembelajaran ini peserta didik akan berperan aktif dalam pembelajaran.

Pada kelas kontrol peneliti lebih aktif memberi informasi kepada peserta didik, dalam pelaksanaan pembelajaran peneliti mengajarkan materi statistika. Proses pembelajaran diawali dengan pemberian materi oleh peneliti kepada peserta didik dan setelah itu peserta didik diarahkan oleh peneliti untuk memperhatikan apa yang peneiti jelaskan dalam pembelajaran materi statistika. Peserta didik pun hanya melihat dan mendengar apa yang dijelaskan oleh peneliti. Kegiatan pembelajaran dalam kelas kontrol yaitu dengan menggunakan model pembelajaran konvensional sudah diterapkan secara baik, dimana ketika ada peserta didik yang tidak paham maka peserta didik tersebut akan bertanya dan begitu juga ketika peneliti memberi pertanyaan pada peserta didik yang mencoba menjawab pertanyaan dari peneliti. Akan tetapi, masih banyak peserta didik yang belum bisa menjawab soal atau pertanyaan yang peneliti berikan, serta masih ada peserta didik yang ngobrol dalam kelas dan tidak mencatat dalam kegiatan pembelajaran yang berlangsung.

Hasil kemampuan penalaran matematis adalah penskoran penalaran matematis peserta didik yang diperoleh melalui tes akhir (posttest) yang terdiri dari 7 soal yang mengacu pada indikator penalaran matematis pada materi statistika. Sedangkan hasil motivasi belajar peserta didik adalah penskoran angket yang terdiri dari 29 pernyataan yang mengacu pada indikator motivasi belajar. Posttest dan angket diberikan pada akhir pembelajaran dengan tujuan untuk mengetahui kemampuan penalaran matematis peseta didik dan motivasi belajar peserta didik terhadap pembelajaran yang telah dilakukan.

Berdasarkan perhitungan test of between-subject effect, tes kemampuan penalaran matematis diperoleh nilai sig. $=0,001$. Karena nilai sig lebih kecil dari 0,05 maka $H_{0}$ ditolak, sehingga dapat disimpulkan bahwa adanya pengaruh model pembelajaran Search, Solve, Create, and Share (SSCS) terhadap kemampuan penalaran matematis peserta didik. Kemudian dari perhitungan test of betweensubject effect, angket motivasi belajar diperoleh nilai sig $=0,043$. Karena nilai sig lebih kecil dari 0,05 maka $H_{0}$ ditolak, sehingga dapat disimpulkan bahwa adanya pengaruh model pembelajaran Search, Solve, Create, and Share (SSCS) terhadap motivasi belajar peseta didik. Sedangkan dari hasil tes Multivariate test, diperoleh nilai sig = 0,003. Karena nilai sig lebih kecil dari 0,05 maka $H_{0}$ ditolak, sehingga dapat disimpulkan bahwa adanya pengaruh model pembelajaran Search, Solve, Create, and Share (SSCS) terhadap kemampuan penalaran matematis dan motivasi belajar peserta didik.

\section{SIMPULAN}

Berdasarkan hasil analisis data dan pembahasan, dapat disimpulkan bahwa: (1) terdapat pengaruh model pembelajaan Search, Solve, Create, and Share (SSCS) terhadap motivasi belajar peserta didik, (2) terdapat pengaruh model pembelajaan Search, Solve, Create, and Share (SSCS) terhadap kemampuan penalaran matematis peserta didik, (3) terdapat pengaruh model pembelajaan Search, Solve, Create, and Share (SSCS) terhadap motivasi belajar dan kemampuan penalaran matematis peserta didik. 


\section{Daftar Pustaka}

A.M, Sardiman. 2016. Interaksi dan Motivasi Belajar Mengajar. 1 ed. Jakarta: Raja Grafindo Persada.

Astuti, N. P. E. F., G. Suweken, dan D. Waluyo. 2018. "Pengaruh Model Pembelajaran Search, Solve, Create and Share (SSCS) terhada Pemahaman Konsep Matematika Siswa Kelas VIII SMP Negeri 1 Banjar.” Jurnal Pendidikan Matematika Undiksha Vol. IX(2):h. 86.

Copriady, Jimmi, dan Rajawali Usma Rery. 2016. "Pembelajaran PBS Tipe Search, Solve, Create Dan Share (SSCS) dengan Molymod untuk meningkatkan Motivasi dan Hasil Belajar Mata Kuliah Kimia Organik II." Jurnal Pendidikan Vol.7(2).

Destyana, Vivi Andyni, dan Jun Surjanti. 2021. "Efektivitas Penggunaan Google Classroom dan Motivasi Belajar Terhadap Hasil Belajar Peserta Didik Mata Pelajaran Ekonomi." Edukatif: Jurnal Ilmu Pendidikan 3(3).

Gorat, Mitro, dan Rahman Haryadi. 2020. "Implementasi Model Pembelajaran Problem Based Learning (PBL) dan Inquiri Based Learning (IBL) terhadap Kemampuan Penalaran Matematis Di Tinjau dari Motivasi Belajar Siswa." Jurnal Prodi Pendidikan Matematika (JPMM) 2(2).

Izzah, Khodijah Habibatul, dan Mira Azizah. 2019. "Analisis Kemampuan Penalaran Siswa dalam Pemecahan Masalah Matematika Siswa Kelas IV." Indonesian Journal Of Educational Research and Review 2(2).

Konita, Mita, Mohammad Asikin, dan Tri Sri Noor Asih. 2019. "Kemampuan Penalaran Matematis dalam Model Pembelajaran Connecting, Organizing, Reflecting, Extending (CORE).” PRISMA, Prosiding Seminar Nasional Matematika 2.

Mirlanda, Ela Priastuti, Hepsi Nindiasari, dan Syamsuri. 2020. "Pengaruh Pembelajaran Flipped Classroom Terhadap Kemampuan Penalaran Matematis Ditinjau dari Gaya Kognitif Siswa." Prima: Jurnal Pendidikan Matematika 4(1).

Ningtiyas, Putri Wahyu, dan Jun Surjanti. 2021. "Pengaruh Motivasi Belajar dan Kemandirian Belajar Peserta Didik Terhadap Hasil Belajar Ekonomi Pada Pembelajaran Daring Dimasa Covid-19." Edukatif: Jurnal Ilmu Pendidikan 34.

Purwanto, Ngalim. 2014. Ilmu Pendidikan Teoritis dan Praktis. 4 ed. Bandung: Remadja Rosdakarya.

Putriyana, Annur Wulan, Lia Auliandari, dan Kholillah. 2020. "Kelayakan Lembar Kerja Peserta Didik Berbasis Model Pembelajaran Search, Solve, Create and Share pada Praktikum Materi Fungi." BIODIK: Jurnal Ilmiah Pendidikan Biologi 6(02).

Safi'i, Ahmad. 2020. "Pengaruh Model Pembelajaran Search, Solve, Create, and Share (SSCS) Terhadap Kemampuan Berpikir Reflektif Matematis Dan Kemampuan 
Pemecahan Masalah Matematis Peserta Didik.” Skripsi, UIN Raden Intan Lampung.

Santosa, Farah Heniati, Habibi Ratu Perwira Negara, dan Samsul Bahri. 2020. "Efektivitas Pembelajaran Google Classroom Terhadap Kemampuan Penalaran Matematis Siswa." 3(1).

Shoimin, Aris. 2018. 68 Model Pembelajaran Inovatif Dalam Kurikulum 2013. Yogyakarta: Ar-Ruzz Media.

Ubaidah, Nila, dan Dyana Wijayanti. 2020. "Model Pembelajaran Model Pembelajaran Search, Solve, Create and Share Bernuansa Islami untuk Meningkatkan Disposisi Matematis Siswa.” UNION: Jurnal Pendidikan Matematika 8(1).

Umairah, Putri, dan Zulfah. 2020. "Peningkatan Motivasi Belajar Menggunakan 'Google Classroom' ditengah Pandemi Covid-19 pada Peserta Didik Kelas XI IPS 4 SMAN 1 BangkinangKota.” Journal On Eduction 02(03).

Uno, Hamzah B. 2013. Teori Motivasi dan Pengukurannya. Jakarta: Bumi Aksara.

Widyati, Fasaila Nadif, dan Hani Irawati. 2020. "Studi Literatur Peningkatan Oral Actvity dan Hasil Belajar Kognitif melalui Penerapan Model Pembelajaran Search, Solve, Create and Share (SSCS) Materi Sistem Ekresi pada Manusia.” INKUIRI: Jurnal Pendidikan IPA 9(2). 